\title{
THE IMPACT OF MOBILITIES ON VISUAL ARTS IN THE SLOVENIAN DIASPORA IN ARGENTINA
}

\author{
Jaka REPIČ
}

COBISS 1.01

\begin{abstract}
The Impact of Mobilities on Visual Arts in the Slovenian Diaspora in Argentina

The article addresses the impact of experiences of mobilities on visual arts in the Slovenian diaspora in Argentina. It aims to explore the question of how artistic creativity is related to individual and collective experiences of migration, life in diaspora and return mobilities. It approaches art as processual, relational and embedded in broader social, political and cultural contexts. Hence, such an analysis facilitates not only an understanding of individual experiences and worldviews, but also of the broader conceptualisation of art within particular socio-historical contexts. It explores how artists in diaspora imagine, express and constitute their relations with the homeland and their understanding of the past. By juxtaposing their art production with their life histories and trajectories as well as broader socio-historical contexts, the article explores intersections and correspondences between mobility and visual art, and raises the question of how diasporic sociality influences artists and their works as well as how artworks in turn create sociality.
\end{abstract}

KEY WORDS: Slovenian diaspora, Argentina, visual art, mobility, anthropology of art

\section{IZVLEČEK}

\section{Vpliv mobilnosti na vizualno umetnost v slovenski diaspori v Argentini}

Članek obravnava vpliv mobilnosti na vizualno umetnost med umetniki v slovenski skupnosti v Argentini. Temeljno vprašanje prispevka je, kako je umetniška ustvarjalnost povezana $z$ individualnimi in s kolektivnimi izkušnjami migracije, $\mathrm{z}$ življenjem $\mathrm{v}$ diaspori pa tudi $\mathrm{z}$ vračanjem. Umetnost obravnava $\mathrm{z}$ antropološkega vidika kot procesualno in relacijsko ter vselej vključeno $\mathrm{v}$ širše socialne, politične in družbene kontekste. Takšna analiza po eni strani razkriva umetnikove izkušnje, predvsem pa širše pomene in vloge umetnosti v specifičnih družbenozgodovinskih kontekstih. Ker avtor obravnava, kako umetniki v diaspori razumejo zgodovino ter kako si zamišljajo, izražajo in ustvarjajo odnose $\mathrm{z}$ domovino, umetniška dela postavlja v odnos z življenjskimi zgodbami in potmi umetnikov ter družbenozgodovinskimi okoliščinami. Pojasnjuje povezave med mobilnostjo in umetnostjo, obravnava medsebojno vplivanje diasporične skupnosti na delo umetnikov in obenem vpliv umetniških del na oblikovanje diaspore.

KLJUČNE BESEDE: slovenska diaspora, Argentina, vizualna umetnost, mobilnost, antropologija umetnosti

Associate Professor of Social/Cultural Anthropology at the Department of Ethnology and Cultural Anthropology, Faculty of Arts, University of Ljubljana, Slovenia; jaka.repic@ff.uni-lj. si. The author would like to acknowledge financial support received from the Slovenian Research Agency (research programme Slovenian Identities in the European and Global Contexts; research core funding No. P6-0187 and bilateral project Art in Diaspora: Anthropological Research of Creativity among Slovenians in Argentina and Return Migrants; BI-AR/15-17-010). 


\section{INTRODUCTION}

This article addresses the issue of art and creativity among Slovenian artists ${ }^{1}$ in Argentina, who have been embedded in social contexts of various mobilities - displacement after the Second World War, resettlement in Argentina, life in diaspora and, since 1990, some of them also in various forms of return mobilities to Slovenia (cf. Toplak 2004). When I conducted ethnographic research among Slovenians in Argentina, various art practices were often shown to be important parts of community building and the preservation of ethnic identity, culture and social memories. Music in particular, but also literature and to a certain extent visual artworks, were imbued with the idea of "Slovenianness", i.e. represented Slovenian culture, the relationship with homeland and memories of migration. Artworks that depicted images of the homeland or migration proved to be collective representations distinctive of the Slovenian diaspora. Nevertheless, these artworks were of course authored and produced through reflection on individual experiences of migration, life in diaspora or "return". They artistically invoked individual and collective migration experiences, struggles of ambivalent identities and life in diaspora with reflections on homeland, memory and identity. Several artists also expressed the dilemma of simultaneous engagement in the Argentinean "art world" and art and cultural production in the Slovenian community. I wondered if these artworks can be understood simultaneously as individual as well as relational and (re)producing specific forms of sociality. Are they primarily a product of complex individual experiences or are they also evocative of socio-historical processes, e.g. of preserving social memories and constructing identity in diaspora? Is art then not merely a form of individual creativity and expression but also a means of creating a space of social communication? As I am interested in the connections between mobilities and art, I begin by presenting some of the basic concepts and later discuss several artists in specific diasporic and post-diasporic social contexts in order to analyse the impact of experiences of (im)mobility on the production of visual art.

\section{ANTHROPOLOGICAL ANALYSIS OF THE ARTS IN VARIOUS CONTEXTS OF MOBILITY}

Mobility has in both the past and the present usually held an ambiguous position in the imaginaries of Europeans and in the social sciences. In the predominantly sedentary societies of Europe, people who lived on the move - such as the Roma people, people who worked and lived in circuses, and various musicians, performers and other artists - were often labelled as vagabonds or nomads, and were both admired and marginalized or even persecuted for their mobile lifestyle. Moreover, until the 1990s the social sciences were also predominantly sedentary-focused. Peter Wynn Kirby (2009) states that the European intellectual

1 I gathered ethnographic data during various periods of fieldwork among the Slovenians in Argentina and among "return" migrants, particularly in 2010/2011 and in 2015 by means of biographic interviews. Most of my research up to 2015 was not focused on art. Specifically on this topic, I interviewed ten artists educated in the fine arts in Argentina. One was an actual migrant to Argentina, five were born to first-generation and four to second-generation migrants. All but two were active in the Slovenian community. In addition, I also used the available published sources on other artists mentioned in the text. 
tradition was based on sedentary logics that understood ethnic groups or nations in essential relationships to their localities or territories. Classical anthropology usually addressed cultures as essentially immobile or at most accounted for cyclical and repetitive mobility as means of maintaining social order (cf. Tsing 1993; Rapport and Overing 2003: 261-263; Glick Schiller, Salazar 2013).

Since the 1990s, under the influences of the post-Cold War world realignment, the development of transport and communication technologies and the intensification of global cultural flows, the so-called "material turn" (see Hicks 2010), "spatial turn" and later "mobility turn" (Sheller, Urry 2006; Urry 2007), were developed in anthropology and generally within the social sciences. Studies of migration eventually resulted in three main foci after 1990: analyses were made using the concepts of transnationalism, diaspora and mobility that reflected on migration studies and proposed new approaches. Some recent discussions have also been critical of globalisation and mobility discourses as overly neglecting the historicity of migration and have also problematized the idea that the contemporary world is always on the move (cf. Friedman 2002; Salazar, Smart 2011). Salazar and Smart, for example, point to immobility as another face of mobility, power relations and social, economic and political inequalities (2011; cf. Sheller, Urry 2006: 207). While some people can easily move across borders and some mobility practices are favoured (particularly tourism), others are confronted with immobility in the sense of the inability to move across political and social borders. Hence, mobilities are diverse as well as socially, economically and politically segmented phenomena that in turn (re)produce further social segmentation. When researching human experiences of mobility, or broader issues of how people establish their lives in various contexts of displacement, migration or diaspora, experiences of immobility also have to be addressed, for example in terms of social relations, place attachment, mythologies of homeland and return (cf. Brah 1996; Ahmed 2003). Art and cultural production in a migratory context open a space of social communication, interaction and intervention that often address these same issues.

While anthropology has long engaged with creative practices and art, relatively little attention has been given to the relationship between art and mobility. Some scholars for example have addressed music in transnational, refugee or diasporic contexts (e.g. Aparicio, Jáquez 2003; Baily, Collyer 2006; O’Neill 2008; Kozorog, Bartulović 2015), whereas performative and particularly visual arts in migration/mobility contexts were less often studied from the anthropological perspective. Hence, the relationship between creativity and individual and social experiences of mobility - in this particular case art in experiences of diaspora and return mobilities - deserve more attention from various focal points. The analysis below partly follows Maruška Svašek's point that art and cultural production are processual and relational. She stresses the "processual nature of art production ... (to) identify the many different factors that influence the ways in which people experience and understand it" (Svašek 2007: 4). The article addresses how artworks by Slovenian artists in diaspora are produced, experienced and conceptualised in their particular socio-historical setting as well as how this conceptualisation and art production relate to socio-historical processes connected to exile, diaspora-building and return mobilities. In this sense, art is not simply an individual or collective product but a relational one, dependent on socio-political processes as well as "different relations between institutions or individuals who produce, consume ... and display artefacts” (Svašek 2007: 5; cf. Becker 1982; Marcus, Myers 1995; Schneider 2006). 
In such an approach, art facilitates not only the understanding merely of individual experiences and worldviews, but also enable insights into broader social, political and historical contexts and the ways artists understand them. Some of the artists I mention below use art to address issues of exile and generation-long constraints on returning, and to express their ideas and imaginaries of living between two homelands. Among some Slovenian artists, we can identify recurrent themes of emigration, exile, homeland and return. These themes appear in literature, music and other art forms, and disclose complex interrelations between personal and social levels of memories, experiences, aspirations and creativity. The artworks reveal how social memories, imaginaries of home and transnational relations are imagined, created and presented in art contexts. The article mainly focuses on the impact of mobility on artistic processes and different social contexts - in the Slovenian diaspora, in different art worlds and in urban spaces.

In analysing the arts as an ethnographic entry point into understanding human experiences as well as their reflections of (im)mobility, the example of the Slovenian diaspora in Argentina presents a particularly interesting case due to its members' experiences of life in exile, generations-long inability to return and eventual possibility to establish various forms of return mobilities (see Repič 2016). Focusing on the ethnographic example of the post-Second World War Slovenian diaspora in Argentina, I point to the collective dimension of experience and social memory of exile as well as living in an ethnic community that was predominantly organised around anti-communist ideological lines and struggled to preserve memories of war, exile and homeland as well as cultural and Catholic traditions and ethnic identity. Hence, I examine various practices of mobility, and particularly artistic reflections of them, in the diasporic contexts outlined below. I start by describing cultural events and various institutions within diasporic community that have been instrumental in facilitating and even institutionalising art and cultural production, and go on to address individual creative practices, discuss certain artists' own interpretations of their work in connection with social memories, experiences of life in diaspora and relationship with the homeland.

\section{PLACE, MEMORY AND THE ARTS IN THE SLOVENIAN DIASPORA IN ARGENTINA}

Historically, there have been several periods of relatively large-scale migration of Slovenians to Argentina, particularly following the First and the Second World Wars, characterised by economic and political emigration from Slovenia (see Žigon 2001; Repič 2006; Molek 2012). In the aftermath of the First World War, a large part of western ethnic Slovenian territory was annexed to Italy, which, combined with poverty and the assimilationist politics of the Italian fascist regime, resulted in the emigration of tens of thousands of Slovenians, around 30,000 of whom settled in Argentina. Another large-scale political emigration occurred after the Second World War, which was directly connected to intra-war fighting between the Slovenian partisans and the anti-communist militas that collaborated with the German occupying army. As the war ended and the German army was forced to retreat, thousands of Slovenians also escaped (or were exiled, as they designate their flight) for fear of retributions during and after the communist revolution in Yugoslavia. These refugees were mainly soldiers of the anti-communist Slovenian Home Guard who 
had collaborated with the German army, but there were also many civilians and political opponents of communism.

The refugees were initially settled in refugee camps in southern Austria and northern Italy, from where they eventually resettled to several European countries, but also to Argentina, Canada and other countries (see Žigon 1998, 2001; Sjekloča 2004; Repič 2006, Švent 2007). The British Army, which managed these refugee camps in Carinthia, initially separated the soldiers from the civilians and repatriated more than 10,000 Slovenians (mostly Home Guard soldiers) to Yugoslavia, where a large majority of them were executed (see Corselis 1997; Ferenc 2005). It is estimated altogether at least 14,000 Slovenians and tens of thousands of non-Slovenians (particularly Croatian and other soldiers of the retreating armies) were more or less secretly executed and buried in mass graves scattered around Slovenia. Between 1947 and 1951 around 6,000 Slovenian refuges migrated to Argentina, where they established a well-organised ethnic community based on shared and socially communicated experiences and memories of exile as well as a clear anti-communist political stance. The Slovenian diaspora in Argentina was primarily established on three main ideological pillars: 1) anti-communism and the preservation of social memories of war, exile, repatriations and extra-judicial executions; 2) ethnicity, language and traditional culture (including Christian values) expressed as commitment to preserve "Slovenianness"; and 3) actual or mythical relationships with homeland. They established several ethnic urban neighbourhoods, churches, local ethnic associations or cultural centres, newspapers, Slovenian schools, and a cultural programme with an art school (see Debeljak 1994; Rant 1998). Traumatic social memories, victimization, the Slovenian language and culture, Christian values and ideas of the homeland and return were persistent themes in the diasporic community and its institutions, especially in schools and during rituals, but also in art and cultural production. ${ }^{2}$ On the one hand its political elite struggled to organise "its own world, independent and dislocated from the homeland" (Rot 1992: 225), whereas on the other there was a steady process of integration into Argentinean society, which also influenced art and cultural production, particularly among younger artists.

Here I focus on the relationship between the socio-historical and individual levels of art and cultural production. To an extent I follow the classical understanding of the analytical term diaspora as proposed initially by William Safran (1991), who defined its main characteristics as a dispersed network of people with traumatic social memories of their displacement, poor integration in the surrounding society, and maintaining relationships with the (ancestral) homeland such as political engagement, mythology of the homeland, and mythology of return. Similarly, Rogers Brubaker (2005) also noted the main characteristics of diaspora in the relationship with homeland and boundary maintenance within wider society. Diaspora, writes James Clifford,

involves dwelling, maintaining communities, having collective homes away from home [...] the term diaspora is a signifier, not simply of transnationality and movement, but of political struggles to define the local, as distinctive community, in historical contexts of displacement. (1994: 308)

2 Most of the Slovenians who settled in Argentina in this period joined the newly-established ethnic community, whereas some chose not to and distanced themselves from it. 
Such a struggle is apparent in the art and cultural production, which enables reflection not only for anthropologists, but more importantly, to members of the diaspora and the surrounding society. The Slovenian diaspora in Argentina was established as a highly organised ethnic community with a main association and several local associations in Buenos Aires, Bariloche and Mendoza. Narratives of exile, forced repatriations and secret executions were preserved in great detail and regularly occur in everyday life during conversations, in schools, church services, various events organised by associations, and political rituals as well as in media, art and cultural production. Moreover, narratives and depictions of homeland, exile, life in Argentina and return are recurrent themes that appear in diverse works of art in its broadest sense, including literature, music and performances (as part of cultural events or celebrations) as well as the visual arts.

Music, particularly choir singing, is well developed and promoted in the Slovenian diaspora as it stands for the preservation of language and cultural tradition as well as a means of strengthening social relationships, for example in schools, during cultural events, political rituals and on the radio programme Window on Slovenia (cf. Mislej 1995; Vovk 2004). Publications (e.g. Svobodna Slovenija; Duhovno življenje; Meddobje, Glas SKA) often included lyrics and even the music of Slovenian songs. Singing in the Slovenian language situationally re-creates and affirms diasporic sociality. Literature is also important and encouraged because of the role of the Slovenian language in the community and the preservation of historical memories of war and post-war events (see Žitnik on literature among Slovenian emigrants). The main association Zedinjena Slovenija (United Slovenia) and particularly the cultural programme Slovenska kulturna akcija (Slovenian Cultural Action) promoted the production and publication of literature in Slovenian (see Mislej 1991, 1992; 1995; Rot 1992; Papež, Eiletz, Jerebič 1994; Žigon 2001: 136-138). The prominent themes in this literature, connected to migration experiences, range from (a) accurate and detailed testimonies, published regularly in books (e.g. Zajec, Kozina, Dejak 1998) or the community bulletin and narrated at ceremonies; (b) literature on war and revolution; and (c) novels and poetry, but even these were sometimes based on the theme of suffering; to (d) school textbooks and general literature on Slovenian history, geography, and ethnology. Even in schools, children were educated about Slovenia, the history of the war, exile, forced repatriations, torture and executions in order to induce a sense of trauma as constitutive to the community. As one of the interlocutors expressed: "We are all here because of the injustice that our parents had to suffer ... I should have been born in Slovenia."

\section{Visual arts in diaspora}

Depictions of the homeland, the war and exile also appear in the visual arts (Toplak 2008; Repič 2006, 2012). Art and cultural production was strongly encouraged as it represented the creativity and rich cultural life in/of the community. Most influential for development of the arts in the diaspora was the cultural programme Slovenian Cultural Action, which was established in order to support literary, philosophical and scientific publications and art exhibitions among the Slovenians in Argentina and later globally. Even though the programme was based in Buenos Aires, it was transnational, incorporating Slovenian artists in Argentina, Canada, Venezuela, the USA, Australia and elsewhere. Its main objective was to connect Slovenian artists and scientists and promote creativity among them, and 
to support art education, but also to preserve Slovenian Catholic traditions and memories of exile.

The arts, however, were also the least explicit in this ideological agenda and detached from the influences of the community political elite for two main reasons. Firstly, even though the Slovenian Cultural Action included an arts section and a school of fine arts, the teachers and participants were reluctant to strictly adhere to the prevailing ideological agenda promoted by the political elite in the community, and primarily aimed to develop spaces for the artistic activities of diaspora members and the education of younger artists (see Rot 1994; Toplak 2003, 2008: 87-101 on the art school and the Slovenian Cultural Action programme). Secondly, especially younger artists were increasingly integrated into and educated in the Argentinean art world. For young Slovenian artists, the school of fine arts, established in 1955, provided them with their first contact with art and the possibility to study with established artists such as France Ahčin, who led the fine arts school, along with Bara Remec, Marijan Marolt and Milan Volovšek, who had a marked influence on the first generation of art students (see Mislej 2001 on Slovenian visual artists in migration and Toplak 2003 on the art school). Even though the school of fine arts only operated for a few years, it was influential in that it established art as an important activity in the diaspora and thus found support within the Slovenian Cultural Action despite the initial ideological split. The Slovenian Cultural Action also promoted a certain level of ideological position and had a huge influence on many artists, in terms of modes, styles and themes that were important for preserving Slovenian identity in diaspora (see Toplak 2008: 94). Initially, art was often appreciated as a means of representing as well as creating and preserving connections to the homeland and memories. While literature often focused on traditional life in Slovenia, the war and the post-war executions, paintings often depicted Slovenian landscapes and specific places in the homeland and later in Argentina. Kristina Toplak writes that initially the conceptualisation of the fine arts was limited to realistic or impressionistic paintings of the pre-war period with explicit national or religious connotations (2008: 98). Later, artists became more embedded in the Argentinean art world - educated at schools of fine arts and also exploring socially relevant topics in their contemporary life in Argentina. In this sense, the production and representations of visual art were least attached to the ideological position of the community, but nevertheless reflected and communicated experiences of migrants and their descendants. Some of the recurrent themes in Slovenian-Argentinian visual arts that are analysed here are (a) violence, migration and memories of war; (b), the Slovenian landscape, homeland and return; (c) the search for identity and ambivalence between the Slovenian diaspora and the Argentinean art world. I shall take these in turn.

\section{Violence, migration and memories of war}

Marjan Grum is a painter, sculptor and performer. In 1987 he set up an art gallery called Museo conventillo Marjan Grum. His gallery is situated in La Boca, an old neighbourhood close to the old port of Buenos Aires, established through immigration and industrial labour. Conventillos were large apartment buildings, usually with a patio (courtyard) or a small communal open-air space, and with many small apartments or rooms where migrants lived together. Argentinean society was built through the history of immigration, 
and Buenos Aires in particular has been characterised as open, multicultural, cosmopolitan, and a place of creativity, art and popular culture (cf. Schneider 2006: 8). The urban multicultural situation generated new kinds of cultural production and art styles. La Boca in particular, as a symbol of labour immigration and cultural pluralism, has become an important tourist destination and offers imaginaries of mass immigration, urbanisation, and national and popular culture, manifesting in art, music, dance and the reinvention of conventillos.

Grum is one of the prominent La Boca artists that renovated and redesigned a conventillo and turned it into an art gallery. He was born in Slovenia in 1939. After the war, his family escaped to Austria, except for his father, a Home Guard soldier who was captured and killed after the war in Kočevski rog. Marjan was initially a self-educated painter and sculptor. He was employed as a blacksmith, and started by forging iron figures and tools. In 1980 he enrolled in the art academy in Moron, Buenos Aires, but only became famous after he settled in La Boca in 1987. He bought an old conventillo on the Calle Garibaldi and renovated it into a local cultural centre called Museo Conventillo Marjan Grum. He lives, works and exhibits in it, but he is also very prominent figure in the local community and in the association of La Boca artists. His work mostly consists of metal sculptures and paintings, which he sells on the main street Calle Caminito as well as in his gallery. $\mathrm{He}$ is best known for his sculpting style of rough iron welded objects, depicting gauchos as well as tango dancers, musicians and similar urban images. Selling sculptures and tourist souvenirs enables him to finance his gallery, in which he exhibits much more diverse and experimental sculptures and paintings.

In his gallery, one can notice influences of his personal experiences of exile and life in the multicultural urban space of Buenos Aires. The gallery has three main exhibition parts, apart from his apartment, workshop and patio in which he greets visitors and holds cultural and musical events. The first part includes artworks connected to La Boca, objects from previous exhibitions, and souvenirs for sale. The exhibited objects present various artistic styles and experimenting with materials and techniques. The second part is an exhibition of the artist's own life history, with a focus on his migratory period and exhibitions and awards. During visits on different occasions, he tour-guided me through the gallery and also dramatically narrated his life story. It was an account that was structured in many details, as it was regularly narrated to visitors. It is indeed a dramatic account of his father's death and the rest of the family being exiled from Slovenia at the end of the Second World War. He exhibited pictures from his life as a child in a refugee camp in Spittal, Austria, the ocean voyage from Genoa to Buenos Aires in 1949, immigration documents, and newspaper articles on his exhibitions in Slovenia and elsewhere in the world.

Memories of exile and nostalgia for his homeland are most clearly apparent in the third part of his gallery, where he exhibited objects depicting images of violence, executions, suffering, death ... He explained how he had dedicated several of his works to his father and other Home Guard soldiers who were killed after the war:

At the executions, they were shot and fell into the pit caves. Some escaped from the caves, my father among them. He managed to climb out of the cave and came to Austria. But he was sent back. I never saw him again.

I have done these in memory of the Home Guard soldiers, but also in memory of my father. It was in a pit cave, in Kočevski rog, where the Home Guard soldiers ended up after they were executed. 
They were killing them in huge numbers in Kočevski rog and in Slovenia. These (paintings) remind me of that.

Marjan Grum engaged in diverse forms of artistic engagement: in La Boca, a micro-location that crucially influenced the themes and styles of his creativity and art representations; in the broader art worlds in Argentina and abroad; and finally in the Slovenian diaspora, especially since his first return to Slovenia in 1994. His exhibited artworks denote his life experiences, engagement in Argentinean society and partial inclusion in the Slovenian diaspora, but also an exploration of issues connected to violence, memories of the war and relationship with the homeland. Grum is not alone in his depictions of memories of violence. Many other Slovenian artists have also explored this issue. For example, Andreja Dolinar did a painting of Kočevski rog, and her sister Marjeta (Margarita) Dolinar is famous for her painting she titled Slovenian Guernica, both conveying images of violence and mass graves.

\section{Landscape, homeland and return}

Another painter, Cecilija Grbec, was born in Buenos Aires in 1977 to a second-generation Slovenian emigrant family - one of her parents was born in a refugee camp, the other in Argentina. She was raised with a strong sense of being an ethnic Slovenian and her family are respected members of the Slovenian community. In Buenos Aires, she was educated in fine arts and graduated with a degree in painting. In addition to her formal art education, she was intensely involved in the work of the main Slovenian association. The cultural and art programme Slovenian Cultural Action particularly influenced her artistic work until she moved to Slovenia in her mid-20s. Grbec has exhibited in Buenos Aires and various other places in Argentina, but also in Slovenia, Austria and Italy. Since she moved to Slovenia, she has travelled back to Argentina many times and periodically stayed and worked there for extended periods. In some of her paintings she has expressed this ambivalence of belonging as a search for home and personal identity, which is apparent in her exhibitions, e.g. one titled Trails of my Roots, Flames of Searching. Her early exhibited works depict images from her childhood, artistic exploration of her roots and origin and places where she either lived, felt connected to, or had a sense of belonging to (cf. Repič 2010). Her art at least in some parts expresses a division between the world she had lived in and the world her ancestors had left behind; but also between memories and myths and lived reality or aspirations for the future. Art reviewer Ana Sitar noticed this ambivalence in her art and described Cecilija's exhibition entitled Trails of my Roots as follows:

In her work, two worlds, two homelands, meet. South America is the world of her childhood, the world where she grew up and where she was constantly aware of another world, the homeland of her ancestors. The diversity of (her) works confirms the eternal connection and interweavement of not only two actual worlds and homelands but the interrelation of the experienced world to the vast world of memory.

Since she moved to Slovenia, she has retained this style, but has also developed new themes - mostly exploring religious images and Slovenia's landscapes and its features, such as 
churches, monuments and various places important in (post)diasporic narratives. Contrary to Marjan Grum, she is not concerned with images of violence, but with home and homeland, conveyed in images of landscape and distinctive, often sacred places. Moreover, religious images are important in Cecilija's work and reflect the crucial role religion has played in her life as well as generally among the Slovenians in diaspora. Similarly to Cecilija Grbec, many other Slovenian-Argentinean artists also produced artworks connected to religion. Marko Jerman for example specialised in stained glass painting and has produced glass windows for many churches in Argentina, Slovenia, Croatia and Austria. He was born in Argentina and migrated to Europe, initially to Italy, where he was educated in Milan in the 1980s in stained glass painting, and then moved to Slovenia in 1991. In 2015, when I was conducting an interview in the house of a Slovenian family in Bariloche, I recognised an image that resembled Mount Jalovec in the Slovenian Alps in a stained-glass painting hanging on the wall. I learned that it had been done by Marko Jerman before even going to Slovenia and before ever actually seeing this particular mountain. In many other artists' work, artistic representations of landscape are powerful symbolic expressions of homeland, identity and belonging (cf. Repič 2016).

One of my interlocutors, Lucia Voršič, who teaches fine arts at a school and critically reflected on art production in the Slovenian diaspora, said that her father also often painted landscapes from his childhood before the exile. Those paintings were dark and invoked sadness and loss. Hence, a specific sense of diasporicity is not represented merely by realistic depictions or accounts, but also by invoking a sense that is shared within their social reality. In this sense, artworks that invoke images of homeland, loss, suffering or nostalgia also have the capacity to also recreate specific memories as well as diasporic sociality. Kristina Toplak writes of another artist who has made many water-themed paintings and noticed its symbolism of fluidity and uncertainty, but also of the distance between the two homelands (2008: 141). Artworks depicting landscapes can be understood as symbolic expressions of identity, belonging and home, but they are more than that. As several artists I talked to put it, they are a means of research into the issue of spatial and social relationships and identifications, which for them, living in diaspora, were never straightforward.

\section{Ambivalence}

We have seen a clear issue of identity ambivalence explored in the artistic works and life trajectory of Cecilija Grbec. As noted by Toplak (2008: 124-133), Andreja Dolinar also expressed her simultaneous embeddedness in the cultural life in the Slovenian diaspora and in the Argentinean art world. She was born in Argentina and was encouraged to study fine arts at a college in Buenos Aires and practice among renowned Argentinean artists. She held her first exhibition at the Slovenian association in 1985, where she exhibited paintings of landscapes and some works with a leitmotif of exile. She established herself as a professional artist in Argentina, but also exhibited in several European countries. She exhibited her artworks in Slovenia in 1994 under the auspices of a programme of the Slovenian Cultural Action that aimed to present the Slovenian community from Argentina through the works of some of its artists. She has been involved with the Slovenian Cultural Action for many years and has established relations with Slovenian artists beyond Argentina. 
Andreja Dolinar noted a difference between the older artists within the Slovenian Cultural Action, who were more realistic and explored images of exile and home, and the younger artists, who developed a more abstract style under modern influences, for example cubism, and are exploring socially relevant topics in Argentinean life. Her works also reflect the influence of life in a diasporic community and in a family in which the parents often spoke of the beauties of the Slovenian landscape or "the Slovenian tragedy". One of her co-authored works is a mural on the wall outside the Slomšek community club in Buenos Aires. It depicts images of Lake Bled, the city of Ljubljana and the urban landscape of Buenos Aires segueing into each other, joined as a single place, thus showing the relations between her two homelands. Even though she was born and raised in Argentina, the history of diaspora is present in her artworks. She put it as follows:

Me and other artists have two paths ... We work in the Slovenian community to which we feel connected and see this as our moral duty. At the same time, we live in a globalised world and work and exhibit in Argentina. This enriches us as we are developing in two cultures. [...] I feel, like many among us, the ambivalence between both homelands. (in Toplak 2008: 130)

Ambivalence is also seen in artworks of many other Slovenian artists that have either explored images connected to Slovenia and migration or appropriated themes from Argentina. Bara Remec, probably one of the most influential early artists and also a teacher at the school of fine arts of the Slovenian Cultural Action, appropriated various themes and styles used in indigenous art in South America (cf. Mislej 2001: 102-103). Marjan Grum, on the other hand, specialised in rough iron welding and made souvenirs and art objects depicting images and issues from Argentinean history and popular culture - ranging from the tango to the repression of the indigenous population. But he also appropriated themes from the history of the Argentinean indigenous population and various socially relevant issues in contemporary Argentina.

Artists and their artworks recreate a specific sociality - Slovenian artists reflected upon their own and social memories and a diasporic attitude towards the issues of memories, homeland, return or contemporary life in Argentina. Some artists have delved on issues ideologically and culturally important to the Slovenian diaspora, and used art to explore memories and ambivalent belonging, whereas other have completely distanced themselves from these dominant issues. Younger artists in particular have strived to develop their career through Argentinean art institutions such as schools, galleries and informal places of art production. But even the Slovenian artists who are now completely integrated into the Argentinean art world sometimes exhibit their artworks in the Slovenian community. This, however, can present issues relating to creative freedom due to persisting expectations within the community of the topics that should be engaged with, and which should be considered taboo. As one interlocutor put it: "The exhibition of nudes would produce a scandal in the community." Several younger artists said that social expectations in the community restrict their creative freedom. One of the artists told me in an interview: "Art has fulfilled and saved me ... also from the community, which I love, but at the same time I needed liberation from the constraints of the community." Another young artist, Daniel Leber, said that he was aware of such expectations and moral norms in the community, but he didn't really see them as obstacles to the creative process, as his career in the art world 
of Buenos Aires enabled him a creative detachment from the community, in which he is nevertheless accepted and respected.

\section{CONCLUSION}

This article focused on the theoretically underappreciated connection between art and mobility using the example of the Slovenian diaspora in Argentina in order to show connections between art, or creativity, and various mobilities. It addressed the question of how social memories, imaginaries of home and relations with a distant homeland are imagined, explored, (re)created and expressed in art. Many Slovenian artists have "returned" to Slovenia at least for visits, or to hold exhibitions, and some have even migrated there. Some of the themes that were important among certain artists addressed issues of exile, return and living between two homelands. In diaspora, the home(land) is constituted as an essential spatial referent: it is not merely a place of origin, but is constituted as a meaningful distant place that belongs to another time (Repič 2016). Return mobilities - migration, visits, roots tourism and other forms of travel between Argentina and Slovenia that are at least on a certain level understood as returning home (cf. King, Christou 2011; Basu 2004, see also criticism of the concept of return migration in Čapo 2010) - engender the re-creation and redefinition of relations with the homeland. Mobilities - such as exile, return or travel due to international exhibitions - constitute varied influences on artists' lives, careers and artworks. Cecilija Grbec and Andreja Dolinar for example, both born in Argentina, express ambivalence in their search for roots. Marjan Grum has also connected art to mobilities - on the one hand exile and on the other hand return and the internationalisation of his career. Several younger artists acknowledge the rich history of art and cultural production in the diaspora, but tend to distance themselves from the perceived social constraints and expectations. Their education, styles and themes all differ and are dependent upon various social contexts and their choices. Nevertheless, we can observe that in different contexts of mobilities, art is a means of imagining, exploring, expressing and creating social relations and relations with distant places and different times. Artworks manifest the re-creation of these relations.

Anthropological analysis of art can present different perspectives than art history and various other disciplines. There is no single and simple answer to the question of what art can tell us about migration and life in diaspora, as there are many layers of socio-historical influences and individual reflections to consider in art and cultural production. In the case of Slovenian artists in Argentina we can see that even though artworks are authored and individually produced, certain collectively established conditions, conceptualisations and various socio-historical processes such as mobilities are closely bound up with and reflected in the art production. Moreover, artworks are more than mere symbols that could be clearly read - art objects are made by individual artists and in turn create these artists. They are not merely tools of representation; these objects are processes of explorations of, and reflections upon, individual and social memories, emotions, identities and life courses. In this sense artists create these objects as much as the objects, or more precisely, the making of the art objects, create both the artists as social actors and their particular sociality. 


\section{REFERENCES}

Ahmed, Sara, Castañeda, Claudia, Fortier, Anne-Marie, Sheller, Mimi (eds.) (2003). Uprootings/Regroundings: Questions of Home and Migration. Oxford, New York: Berg.

Aparicio, Frances R., Jáquez, Cándida F. (eds.) (2003). Musical Migrations: Transnationalism and Cultural Hybridity in Latin/o America. New York: Palgrave Macmillan.

Baily, John, Collyer, Michael (2006). Introduction: Music and Migration. Journal of Ethnic and Migration Studies 32/2, 167-182.

Basu, Paul (2004). Route Metaphors of 'Roots-Tourism' in the Scottish Highland Diaspora. Reframing Pilgrimage: Cultures in Motion (eds. Simon Coleman, John Eade). London: Routledge, 150-174.

Becker, Howard (1982). Art Worlds. Berkeley: University of California Press.

Brah, Avtar (1996). Cartographies of Diaspora: Contesting Identities. London, New York: Routledge.

Brubaker, Rogers (2005). The "Diaspora” Diaspora. Ethnic and Racial Studies 28/1, 1-19.

Clifford, James (1994). Diasporas. Cultural Anthropology 9/3, 302-338.

Corsellis, John (1997). The Slovenian Political Emigration 1945-1950. Dve domovini / Two Homelands 8, 131-159.

Čapo Žmegač, Jasna (2010). Return Migration: The Changing Faces and Challenging Facets of a Field of Study. Ethnologia Balkanica 14, 227-245.

Debeljak, Tine (1994). Slovenski srednješolski tečaj ravnatelja Marka Bajuka v Buenos Airesu. Življenje in delo Slovencev v Argentini (po letu 1945). Ljubljana, Washington: Studia Slovenica, 42-48.

Ferenc, Mitja (2005). Prikrito in očem zakrito: Prikrita grobišča 60 let po koncu druge svetovne vojne. Celje: Muzej novejše zgodovine.

Friedman, Jonathan (2002). From Roots to Routes: Tropes for Trippers. Anthropological Theory 2, 21-36.

Glick Schiller, Nina, Salazar, Noel B. (2013). Regimes of Mobility Across the Globe. Journal of Ethnic and Migration Studies 39/2, 183-200.

Hicks, Dan (2010). The Material-Cultural Turn: Event and Effect. The Oxford Handbook of Material Culture Studies. Oxford: Oxford University Press, 25-98.

Kozorog, Miha, Bartulović, Alenka (2015). The Sevdalinka in Exile, Revisited: Young Bosnian Refugees' Music-making in Ljubljana in the 1990s (A Note on Applied Ethnomusicology). Narodna umjetnost 52/1, 121-142.

King, Russel, Christou, Anastasia (2011). Of Counter-Diaspora and Reverse Transnationalism: Return Mobilities to and from the Ancestral Homeland. Mobilities 6/4, 451-466.

Kirby, Peter Wynn (2009). Lost in "Space": Anthropological Approach to Movement. Boundless Worlds: An Anthropological Approach to Movement (ed. Peter Wynn Kirby). New York, Oxford: Berghahn Books, 1-27.

Kocmur, Marijan (1965-1971). Odprti grobovi 1-4. Buenos Aires: Editorial Baraga.

Marcus, George E., Myers, Fred R. (eds.) 1995. The Traffic in Culture: Refiguring Art and Anthropology. California: University of California Press.

Mislej, Irene (1991). Slovensko šolstvo v Argentini. Slovenski koledar 38, 187-90.

Mislej, Irene (1992). Slovenski tisk v Argentini po drugi svetovni vojni. Dve domovini / Two Homelands 2-3, 185-194. 
Mislej, Irene (ed.) (1995). Kulturno ustvarjanje Slovencev v Južni Ameriki. Ljubljana: Znanstveni inštitut Filozofske fakultete.

Mislej, Irene (2001). Pregled slovenskih izseljenih likovnih ustvarjalcev. Slovensko izseljenstvo: Zbornik ob 50-letnici Slovenske izseljenske matice, 1951-2001. Ljubljana: Slovenska izseljenska matica, 89-105.

Molek, Nadia (2012). Ser esloveno en Argentina. Análisis antropológico de las diversas construcciones de eslovenidad: Thesis de Licenciatura. Buenos Aires: Universidad de Buenos Aires, Facultad de Filosofía y Letras.

O’Neill, Maggie (2008). Transnational Refugees: The Transformative Role of Art? Qualitative Social Research 9/2. Art. 59, http://nbn-resolving.de/urn:nbn:de:0114-fqs0802590.

Papež, France, Eiletz, Marijan, Jerebič, Stanko (eds.) (1994). Zbornik Slovenske kulturne akcije 1954-1994. Celje: Mohorjeva družba.

Rant, Jože (1998). Zbornik dela v zvestobi in ljubezni - Zedinjena Slovenija 1948-1998. Buenos Aires: Društvo Zedinjena Slovenija.

Rapport, Nigel, Overing, Joanna (2003). Social and Cultural Anthropology: The Key Concepts. London, New York: Routledge.

Repič, Jaka (2006). 'Po sledovih korenin': Transnacionalne migracije med Argentino in Evropo. Ljubljana: Filozofska fakulteta.

Repič, Jaka (2010). Ambivalent Identities Emerging in Transnational Migrations between Argentina and Slovenia. Dve domovini / Two Homelands 31, 121-134.

Repič, Jaka (2012). Umetnost, urbanost in diaspora: Kulturni center Museo conventillo Marjan Grum v Buenos Airesu. Antropološki vidiki načinov življenja v mestih (eds. Jaka Repič, Jože Hudales). Ljubljana: Znanstvena založba Filozofske fakultete, 211-230.

Repič, Jaka (2016). Tracing roots: Slovenian diaspora in Argentina and return mobilities. Moving Places: Relations, Return, and Belonging (eds. Nataša Gregorič Bon, Jaka Repič). New York, Oxford: Berghahn books, 85-104.

Rot, Andrej (1992). Slovenski tisk v Argentini po drugi svetovni vojni. Dve domovini / Two Homelands 2-3, 209-235.

Rot, Andrej (1994). Republika duhov: Štiridesetletnica Slovenske kulturne akcije. Ljubljana: Državna založba Slovenije.

Safran, William (1991). Diasporas in Modern Societies: Myths of Homeland and Return. Diaspora 1/1, 83-99.

Salazar, Noel B., Smart, Alan (2011). Anthropological Takes on (Im)mobility. Identities: Global Studies in Culture and Power 18, i-ix.

Sheller, Mimi, Urry, John (2006). The New Mobilities Paradigm. Environment and Planning $38,207-226$.

Schneider, Arnd (2006). Appropriation as Practice: Art and Identity in Argentina. New York, Basingstoke: Palgrave MacMillan.

Sjekloča, Marko (2004). Čez morje v pozabo: Argentinci slovenskih korenin in rezultati argentinske integracijske politike. Celje: Fit media.

Svašek, Maruška (2007). Anthropology, Art, and Cultural Production. London, Ann Arbor: Pluto Press.

Švent, Rozina (2007). Slovenski begunci v Avstriji 1945-1950. Ljubljana: ZRC SAZU.

Toplak, Kristina (2003). Umetniška šola Slovenske Kulturne Akcije. Dve Domovini / Two Homelands 18, 135-143. 
Toplak, Kristina (2004). Dobrodošli doma? Vračanje slovenskih izseljencev v Republiko Slovenijo. Dve domovini / Two Homelands 20, 35-51.

Toplak, Kristina (2008). 'Buenas Artes': Ustvarjalnost Slovencev in njihovih potomcev v Buenos Airesu. Ljubljana: Založba ZRC SAZU.

Tsing, Anna L. (1993). In the Realm of the Diamond Queen: Marginality in an Out-of-the-Way Place. Princeton: Princeton University Press.

Urry, John (2007). Mobilities. Cambridge, Malden: Polity.

Vovk, Joži (2004). Antropologija glasbe: Slovenska glasbena kultura in njen vpliv na ohranjanje etnične identitete med Slovenci v Argentini. Diploma thesis. Ljubljana: University of Ljubljana, Faculty of Social Sciences.

Zajec, Milan, Kozina, France, Dejak, France (1998). Ušli so smrti: Poročila treh rešencev iz množičnega groba v Kočevskem Rogu. Celovec, Ljubljana, Dunaj: Mohorjeva založba.

Žigon, Zvone (1998). Otroci dveh domovin: Slovenstvo v Južni Ameriki. Ljubljana: ZRC SAZU.

Žigon, Zvone (2001). Iz spomina v prihodnost: Slovenska politična emigracija v Argentini. Ljubljana: ZRC SAZU.

Žitnik, Janja (2003). Književnost slovenskih izseljencev. Slovensko izseljenstvo: Zbornik ob 50-letnici Slovenske izseljenske matice, 1951-2001. Ljubljana: Slovenska izseljenska matica, 77-88. 


\section{POVZETEK}

\section{VPLIV MOBILNOSTI NA VIZUALNO UMETNOST V SLOVENSKI DIASPORI V ARGENTINI \\ Jaka REPIČ}

Članek obravnava vpliv mobilnosti na ustvarjalnost med likovnimi umetniki v slovenski skupnosti, ki so jo v Argentini oblikovali povojni migranti. Teoretski okvir sloni na povezavi med mobilnostjo in umetnostjo in obravnava povezanost umetniške ustvarjalnosti $\mathrm{z}$ individualnimi in s kolektivnimi izkušnjami migracije, življenjem v diasporični skupnosti pa tudi s povratnimi mobilnostmi v domovino. Analiza sooča izkušnje begunstva po drugi svetovni vojni, ki so ga povzročili medvojna kolaboracija in strah pred povojnim komunističnim režimom, pa tudi izkušnje življenja v diasporični skupnosti, nezmožnost ali odklanjanje vrnitve v domovino do leta 1990 in navsezadnje različne oblike povratnih mobilnosti po slovenski osamosvojitvi leta 1991. Članek na kratko predstavi zgodovino migracije in oblikovanja skupnosti, predvsem pa poudari nekatere temeljne družbenozgodovinske okoliščine, ki so v diaspori oživile socialni spomin na begunstvo in povojne poboje, migracijo v Argentino ter oblikovanje odnosov do domovine.

Članek umetnost obravnava $\mathrm{z}$ antropološkega stališča, torej skozi njeno procesualnost, relacijskost in vključenost v širše politične, zgodovinske in družbene kontekste, predvsem pa se osredotoča na likovno in kiparsko umetnost. Likovna umetnost je bila najbolj odmaknjena od ideoloških agend politične elite v skupnosti, a kljub temu razkriva nekatere temeljne vsebine, s katerimi so umetniki raziskovali, predstavljali in oblikovali diasporično družbenost. Avtor obravnava slovenske umetnike t. i. povojne migracije, njihova umetniška dela pa predstavi skozi tri glavne tematike: socialni spomin na vojno in migracijo, odnos do domovine in ambivalentnost oz. razpetost med dvema družbenima svetovoma. Pri tem ostaja na področju antropologije umetnosti, saj ga zanimajo vplivi med družbenozgodovinskimi okoliščinami, osebnimi izkušnjami in socialnimi spomini ter ustvarjalnostjo. Takšna analiza po eni strani razkriva umetnikove izkušnje, predvsem pa širše pomene in vloge umetniškega delovanja v specifičnih družbenozgodovinskih kontekstih. Ker avtor v članku obravnava, kako slovenski umetniki v diaspori razumejo preteklost ter kako si zamišljajo, izražajo in ustvarjajo odnose z domovino, umetniška dela postavlja v odnos z njihovimi življenjskimi zgodbami in potmi ter družbenozgodovinskimi okoliščinami. 